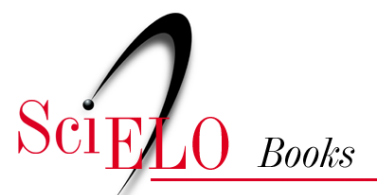

\title{
Prefácio
}

\section{Franca Basaglia}

\section{SciELO Books / SciELO Livros / SciELO Libros}

BASAGLIA, F. Prefácio. In: AMARANTE, P.D.C. O homem e a serpente: outras histórias para a loucura e a psiquiatria [online]. Rio de Janeiro: Editora FIOCRUZ, 1996, pp. 11-12. ISBN 978-85-7541-327-2. https://doi.org/10.7476/9788575413272.0001.

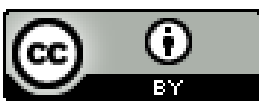

All the contents of this work, except where otherwise noted, is licensed under a Creative Commons Attribution 4.0 International license.

Todo o conteúdo deste trabalho, exceto quando houver ressalva, é publicado sob a licença Creative Commons Atribição 4.0.

Todo el contenido de esta obra, excepto donde se indique lo contrario, está bajo licencia de la licencia $\underline{\text { Creative }}$ Commons Reconocimento 4.0. 


\section{Prefácio}

Na Itália, há quase 20 anos da emanação da lei da reforma psiquiátrica, finalmente o governo prevê o fechamento completo dos manicômios até o fim de 1996.

Durante esses anos as resistências foram fortes, e o clima político-social cada vez mais hostil. Mas muitas 'práticas', muitas experiências - mesmo se muito heterogêneas entre si-estavam e estão testemunhando que a mudança cultural e institucional é possível.

Isso traz à tona um dos nós problemáticos do pensamento e da ação de Franco Basaglia: a 'primazia da prática', da qual se pode ler o porquê da sobrevivência dessa nossa batalha, mesmo nos tempos nos quais se fecharam ainda mais os espaços de expressão, tanto do sujeito individual quanto daquele coletivo. Primazia de uma prática entendida não apenas como mero 'fazer', mas como produtora de uma outra realidade e de uma outra cultura, tendo que lidar, seja com o preconceito social para com o doente mental, seja com o preconceito científico para com a doença.

Não se tratou de uma simples mudança de teoria, substituível com uma nova ideologia de recâmbio, mas da demolição concreta de uma cultura, possível somente se, contemporaneamente, outras culturas pudessem ser construídas: outra sustentação, outro suporte, outro conceito de saúde e de doença, de normalidade e de loucura.

Possivel no sentido de que, se junto com o desmantelamento dos velhos hospitais, não se ficasse limitado a organizar simples serviços ambulatoriais; mas se criou, para os velhos e novos doentes, a possibilidade de viver de maneira diversa o próprio sofrimento, visto como o produto de um conjunto de fatores e não apenas como sinal de periculosidade social a reprimir.

A esse sofrimento, que se revela cada vez mais complexo e ao mesmo tempo mais simples, ocorre responder com estruturas e serviços que consintam formas de cura e de assistência que sejam conjuntamente espaços de vida, de estímulo, de confronto, de oportunidades, de relações interpessoais e coletivas diferentes, que vislumbrem uma mudança de cultura e de política mais social que sanitária.

O manicômio está ainda presente: todavia faltam serviços e estruturas adequadas; a qualidade de intervenção é muitas vezes decadente e insuficiente, muitos familiares denunciam o fato de ter que arcar, muitas vezes sem auxílio ou com pouco apoio, com o peso do parente doente. Mas ninguém quer mais o manicômio. Mesmo que 
novos desafios nos esperem ao enfrentar o 'fazer-se instituição' na cotidianidade de nossa vida, mesmo se o risco do transformismo, de uma mudança formal das etiquetas sobre as velhas instituições seja um perigo real, a cultura da exclusão total - do delegar às paredes, às chaves, aos portões, à violência gratuita e desumana passada pela terapia - está vencida. E não somente na Itália.

As experiências de luta contra o manicômio no Brasil, como em outros países do mundo, são um testemunho. Como é um testemunho este livro que, no âmbito de uma reconstrução dos momentos salientes da história da psiquiatria, segue a evolução da experiência italiana como ponto de referência às práticas de mudanças em cena no Brasil.

Franca Basaglia Veneza, abril de 1996 